\title{
Uncharted Waters? Cultures of Sea Transport and Mobility in New Zealand Colonial History
}

FRANCES STEEL

On a tour of Australia, New Zealand and Fiji in 1909, assistant undersecretary of state for the colonies Sir Charles Lucas ventured to suggest "that in Australia the "bush" must necessarily have a greater effect on the future than in New Zealand, and that in New Zealand the sea will play a greater part in the call of the race than in Australia'. The 'back blocks', he remarked, 'have more especially fashioned Australian life and character'. Although brief and impressionistic, his assessment of the relationship between geography, identity and the course of history still resonates today. The bush is a defining symbol of the Australian imagined community, an enduring source of scholarly and popular inspiration and debate. ${ }^{2}$ Yet, as the Australian national anthem proclaims, the island continent is also 'girt by sea'. In light of Lucas's predictions about the formative influence of the sea in New Zealand, it is perhaps striking to note that while there have been a number of landmark Australian maritime histories, notably Geoffrey Blainey A Tyranny of Distance (1966), John Bach A Maritime History of Australia (1976), and Frank Broeze An Island Nation (2000), New Zealand boasts no equivalent.

Our origin stories are steeped in the sea, from the fishing up of the North Island to the arrival of Canterbury's 'first four ships'. It is also widely recognized that maritime industries shaped the economic and encounter histories of early New Zealand. Yet histories of the colonial period appear to gradually 'dry out' as the nineteenth century progresses. A large and diverse body of work written primarily for a popular audience engages with the place and influence of the sea in New Zealand history. Universitybased historians, by contrast, have been somewhat slower to examine in any systematic way the human relationship to the oceans that surround us and connect us to the world. One aim of this article is to examine this unevenness and comparative neglect. As New Zealand history turned inwards, away from the imperial tradition in history writing, land became entrenched as the natural setting for, and proper subject of, national history. It has been more challenging to craft independent and distinctive 'island stories' from the perspective of the sea, a space that came to symbolize dependence on 
Britain, and the distance and ambivalence which strikes at the heart of what J.G.A. Pocock identifies as the 'antipodean perception'. ${ }^{3}$ New Zealand colonial history became 'unmoored' from the maritime empire and, at the same time, increasingly insulated from the regional currents of the Tasman Sea and the Pacific Ocean.

Land is central to settler colonialism, and questions of land alienation, transformation and use go the heart of New Zealand politics. In this article, however, I argue for the timeliness of a 'sea turn' in approaches to New Zealand colonial history, focusing primarily on Pākehā rather than indigenous cultural forms, for Māori knowledge of and engagement with the oceanic world would require a different sort of history. I begin with a brief discussion of the emergence and evolution of maritime history as a disciplinary sub-field, and then narrow my focus to address approaches to shipping history in particular. I point to the ways in which maritime history might be brought into productive dialogue with the turn to culture in the wider historiography of transport and mobility history. I develop this argument with particular reference to the age of steam, for the changes heralded by the industrialization of shipping are central in understanding cultural histories of communication in the colonial period. By bringing histories of sea transport, mobility and colonialism together in new ways, and by locating the New Zealand historical experience in a global story about the rise of steam, I suggest some productive directions for a reinvigorated scholarship of the maritime world, one which embraces the ship as a key site of historical enquiry and which embeds New Zealand in the wider Pacific world.

\section{Maritime histories: from old to new?}

Maritime history, broadly defined, is the study of human interaction with rivers, seas and oceans. The field developed with a strong grounding in economic, business and labour history, and a primary focus on ships and navigation, naval strategy, exploratory voyages and seaborne commerce. Whereas much early scholarship was characterized by a narrow antiquarianism, by the early 1990s significant shifts in approach to the study of the maritime past were recorded. Newer work in the field, Frank Broeze remarked, had been 'emancipated from its often uncritical, nationalist and anecdotal origins', while David M. Williams stressed that maritime history was now less descriptive and more analytical. ${ }^{4}$ Broeze was less optimistic about the future of maritime history, concluding that its practitioners faced challenges in their 'external relations' with the wider discipline. Maritime history was still widely regarded as too specialized and narrow, pursued mainly for a utilitarian rather than an academic purpose. ${ }^{5}$ While there was a certain awareness of the wider significance and importance of the 
maritime past, without a strong institutional commitment to the field, little sustained scholarship could emerge. Broeze made reference to New Zealand history to illustrate this point. The cover image of the second edition of The Oxford History of New Zealand was a painting of a portscape: Sydney Lough Thompson's Lyttelton from the Bridal Path (1937). Yet the volume's chapters made little reference to the maritime setting. ${ }^{6}$ Maritime history, Broeze stressed, 'must come out of the closet'. But before it could make a systematic contribution and impact, its practitioners had to resolve an 'identity crisis'. The field suffered from a lack of certainty, unity or sense of purpose, in part a result of the long-standing division in historical approaches to the merchant and naval marines?

Sixteen years have passed since this discussion of maritime history 'at the crossroads'. If anything, the perceived problems of fragmentation and lack of unity have been magnified in the intervening years. Maritime history has now 'burst its bounds', as Kären Wigen remarks, with sea-focused studies now produced by a much larger number of practitioners who draw on a range of disciplinary perspectives and ideas, particularly from cultural and postcolonial history, gender studies and historical geography. ${ }^{8}$ The subaltern worlds of seafarers and port dwellers have received increasing attention, with new insights brought to bear on shipboard labour relations and the connections between ship and shore. Ships and littoral communities are typically approached as cosmopolitan 'contact zones', with scholars emphasizing boundary-crossings and transgressions to examine the ways in which 'social and cultural differences were made, negotiated and contested in and through the geographies of ship, shore and ocean'. ${ }^{9}$ The intervening years have also witnessed a marked growth in oceanic or ocean-basin history, which analyzes regions on the basis of shared sea space..$^{10}$ History, in short, is being retold from the perspective of the sea, and, while space prohibits a more detailed discussion here, it is clear, as Glen O'Hara remarks, that there has been an 'explosive and unstable expansion of meaning.' ${ }^{11}$

It is worth noting that for some commentators it is a "cruel current paradox' that 'most of the creative work' is being produced by scholars who do not self-identify as maritime historians. ${ }^{12}$ For others, this creativity strays too far from the groundwork laid by earlier scholars. The editors of the International Journal of Maritime History responded with 'dismay' and 'outright indignation' to the forum 'Oceans of history', published in the American Historical Review in 2006. All of the articles failed to acknowledge or engage with the texts they regarded as formative in the field. ${ }^{13}$ While we might be witnessing the emergence of a 'new' maritime history, it exists in a rather complex, if not fraught, relationship with more established approaches. ${ }^{14}$ 
Where does New Zealand history sit in relationship to these developments? One way, perhaps, to track this is through The New Oxford History of New Zealand, published in $2009 .{ }^{15}$ Does this volume illustrate a richer or more systematic engagement with the oceanic world than the earlier collection published in 1992? The cover image depicts a rural scene. In the Rita Angus painting, Fog, Hawke's Bay (1966-68), a sheep truck passes through a small farming community, sharing the road with a herd of cattle. The index supports this orientation, listing extensive entries for land and numerous entries for sheep. There are no entries for sea, ships or shipping. In turn, no articles dedicated to maritime themes have appeared in the New Zealand Journal of History in the past ten years. Across the life of the journal, Erik Olssen's 1985 study of seamen's union militancy stands as a lone contribution. ${ }^{16}$

As I suggested earlier, a wider discussion of publishing activity in maritime history and heritage studies reveals a much richer picture, indicative of an enduring level of popular interest in the sea-focused dimensions of New Zealand history. Studies encompass local histories of ports, social histories of whalers, seafarers and lighthouse keepers, accounts of shipwrecks, catalogues of iconic ships, as well as more general surveys of maritime industry. ${ }^{17}$ Yet Broeze's remarks about the academic marginalization of maritime history and the prominence of a kind of blinkered vision, one that acknowledges the importance and influence of the sea but which does not translate into sustained analysis, still resonates in New Zealand.

At this point it is helpful to return to Broeze, who, in an earlier article, delineated areas of enquiry of particular interest to maritime historians. These include: the study of the use of the sea's resources; the use of the sea for transport; the use of the sea for the projection of power; scientific exploration of the maritime environment; sea-focused leisure pursuits; and the sea in culture and ideology. These categories are not strictly separate, for they tend to overlap and shape each other. ${ }^{18}$ Returning to the The New Oxford History of New Zealand with these thematic concerns in mind, the sea is not altogether absent. In fact, Part One of the collection is entitled 'People, Land and Sea'. Paul Star addresses environment change from the time of human settlement, cataloguing European floral and faunal introductions, the grasslands revolution and the developing environmental awareness of Pākehā over the course of the last 150 years. Star remarks that seas could never be controlled or transformed in the same ways as terrestrial environments. From a collective European point of view, in sharp contrast to Māori, 'the sea had never gained the same importance as the land'. It was simply a space between New Zealand and overseas markets, a space of transit and a trading channel, rather than a resource pool. ${ }^{19}$ These are valid points from the position of an environmental historian. Yet in a broader sense, 
this perspective reinforces rather than unsettles dominant understandings of the sea as a space outside history: timeless, unchanging and peripheral. The non-indigenous exploitation of marine resources may have a rather thin colonial history, but this is not the final word on the historical relationship between people, land and sea.

In the remainder of this article I turn to consider another sub-field of maritime history in greater depth: the use of the sea as a transport space. Given the landwards orientation of colonial history, studies of early European migration and settlement demonstrate the most systematic attention to transoceanic mobility. But even here the sea typically figures as a space of origin and arrival, an unruly element migrants had to 'get over', as a number of book titles suggest. ${ }^{20}$ Oceanic crossings effectively serve as curtain-raisers to history on shore. The ocean recedes as settlers turned inwards and worked to transform the land to support new life-ways, even if Pākehā, as Pocock suggests, continually 'remember a voyage before they imagine a land'. ${ }^{21}$ In this respect, prominent ships in colonial history are the migrant ships. In an earlier tradition of New Zealand history writing, as Chris Hilliard has argued, an emphasis on the 'first ships' functioned as a mode of effacement. European transoceanic mobilities were originary, depositing newcomers on the shores of an empty or 'waste' land. ${ }^{22}$

Scholarly emphasis on the migrant passage has served to obscure the rich history of oceanic crossings in the decades and centuries prior to European awareness of the Pacific. ${ }^{23}$ It has also directed our attention away from the passages of the workaday vessels, whether local, international or 'foreign', which were engaged in the more mundane but necessary activity of keeping colonial settlements afloat and firmly anchored in regional and global exchange networks in the decades following systematic colonization. References to these routine sea crossings, situated in a longer tradition of economic history, tend to emphasize tonnage cleared inwards and outwards, and the circulation of commodities - frozen meat, mails and books - more often than people. ${ }^{24}$ Hilliard remarks that 'a settler society's cultural inputs do not cease with its "first ships", and they emanate from other places as well as the imperial metropolis'. ${ }^{25}$ Yet ships were not simply the bearers of material and ideological influences from the outside world, or the connecting link between our primary producers and British Homeland consumers. Ships were also used routinely by 'settlers' to keep on moving. ${ }^{26}$

Seaborne mobility shaped the everyday rhythms of colonial life in New Zealand. The popular enthusiasm for travel often made an impression on visitors. On an official tour in 1913 as part of his involvement in the Dominions Royal Commission, Edward J. Harding was struck by the number of people who moved about on steamships and trains. 'I don't know whether it is the effect of a 15,000 mile journey on the generation that makes it so or 
its successor' (hinting at Pocock's point that every voyage was 'remembered, repeatable'), but the word 'trip', he remarked, 'must be one of the ones in commonest use in a New Zealander's vocabulary'. ${ }^{27}$ Harding reflected further on this notable 'zest for travel', surmising that 'perhaps this mobility of body is the cause of the mobility of mind which has made New Zealand the home of so many social experiments'. ${ }^{28}$ The conceptual links drawn here between personal mobility, social vitality and political dynamism were typical of the period. Circulation and motion were understood as civilized, progressive and enlightened, and improved means of transport and communication in the form of rail, steamship and telegraph were assigned a high cultural value. ${ }^{29}$ The belief that technologies of mobility conferred social benefits was deeprooted and widely held, observes British mobility historian Colin Divall, citing Thomas Macaulay, who, in 1849, proclaimed that 'every improvement of the means of locomotion benefits mankind morally and intellectually as well as materially'. ${ }^{30}$

We can track colonial enthusiasm for steam-powered shipping back to at least the mid-nineteenth century, long before regular transport services were an everyday reality. New Zealand's geographical location at the far reaches of empire meant colonists understood keenly the advantages of faster, safer, cheaper and more predictable shipping. Simply put, remarked the Otago Witness in 1853, 'by steam the sense of distance is destroyed'. ${ }^{31}$ Distance meant remoteness, and remoteness could be a form of incarceration. In the same year, Henry Sewell described the arrival of a P\&O boat, 'a real Passenger Steamer', as akin to 'unlocking the door of a prison'. ${ }^{32}$ Steam also promised to collapse domestic distance, making 'a scattered troop of settlements one united colony!' enthused an editorial in the Nelson Examiner in $1851 .^{33}$ A steamer, the writer went on, 'would be an agreeable thing': 'we could make trips in her on pleasure or business to all the settlements, see how older colonists have got on, and observe the conditions of the latest "pilgrims". ${ }^{34}$ This suggests that the physical experience of travel along new steam-driven routes had a particular cultural power. It also supports Tony Ballantyne's point that rather than 'New Zealand' being 'fully formed' at 1840 , the gradual development of transport and communication networks points to the 'constantly in-process status' of the nation as a coherent spatial unit. ${ }^{35}$

At mid-century, these transformations were still confined to booster columns in the colonial press. Commentators quickly grew weary with such talk. As the Nelson Examiner put it, 'shall we recapitulate again for the twentieth time the advantage which Steam communication would bestow upon us?'36 This impatience was a by-product of the fraught technical history of the steamship, for the construction of safe and efficient vessels suited to long ocean passages was enormously challenging. Steam really 
only came of age at the end of the century with the development of more efficient propulsion mechanisms and the introduction of steel as a structural material. Shipownership was transformed by this point too, from private syndicates and single-ship ventures to the company model, which provided more concentrated and professional operations. The closing decades of the nineteenth century marked the rise of the Union Steam Ship Company of New Zealand. Founded in Dunedin 1875, it gradually extended services around the coastal trades, across the Tasman and into the Pacific. Its monopolistic grip over regional shipping earned it the title 'The Southern Octopus. ${ }^{37}$

By the turn of the century, the growth and expansion of maritime industry was frequently deployed as an index of colonial development and maturity. As the New Zealand Official Year Book remarked in 1893, the Union Steam Ship Company's history 'is a reflex, to a great extent, of the later history of the colony - as the one has grown, the other has expanded'.$^{38}$ Newspaper reports of each new addition to the company's fleet made particular reference to tonnage, effectively a shorthand for colonial progress. On the occasion of the arrival of a new intercolonial or trans-Tasman steamer in 1905, for example, the Union Steam Ship Company's history was said to 'read like a romance'. The total tonnage of the company fleet at its foundation in 1875 was 4000 tons; 30 years later it had grown to 112,000 tons. The Evening Post remarked that the company had the progressive qualities 'usually ascribed to the colony as a whole'. ${ }^{39}$

The celebratory and progressive ‘colony-to-nation' narrative has been unsettled in recent years. This was one stated aim of The New Oxford History of New Zealand. It is not my intention to rehabilitate that narrative here through the 'power of steam'. In his discussion of approaches to the history of technology, James Smithies addresses the limitations of myths of progress bound to notions of technological advance. He highlights the problems of technological determinism. Innovations cannot be said to "change society' or to 'drive history' in and of themselves. ${ }^{40}$ Yet transport technologies present a particular set of challenges, for what Divall calls 'techno-myths' of the inherent social value of efficient and cheap personal mobility have been (and continue to be) very difficult to shift. To attend to the ways in which these belief systems get activated in everyday life is perhaps more productive than debating their truth or falsity. ${ }^{41}$

I have pointed to the colonial investment in and attachment to advances in transport technology in order to emphasize that the steamship was a prominent object in everyday life. Cataloguing the public, archetypal expressions of a certain 'steam mindedness' over the course of the nineteenth century can only take us so far. To understand better the enthusiasm for the 'trip', entrenched, it seems, by the 1910s, and the individual and collective 
attitudes and behaviours, the habits and sensibilities, which shaped colonial mobility cultures requires a different sort of analysis. Recent developments in transport history offer a useful conceptual framework.

\section{A colony of 'trippers'? Putting mobility back into transport history}

Traditional transport history, like maritime history itself, has been shaped predominantly by economic, technical and labour-based analyses. The survival of extensive state, company and trade union records helps to explain this. ${ }^{42}$ Insights into the development of infrastructure, the relationship between private enterprise and government policy, and the nature of industrial disputes are all needed if the production and operation of transport and communication systems are to be properly understood. ${ }^{43}$ Yet the tendency to privilege infrastructure over 'behavioural norms and practice' means we still know very little about transport's wider social impact, as well as the more intimate, 'lived histories' of the people who used, or were excluded from, transport in the past. ${ }^{44}$

A paradigm shift, described as the 'history of transport turned history of mobility', decentres the vehicle as an artefact or object to embrace a wider, more inclusive definition of transport. ${ }^{45}$ As Divall outlines with reference to rail-based mobility, this includes the 'subjects' who used, moved or were affected by transport, including workers, traders and passengers; the 'objects', or the 'physical and ideal processes that produce mobility', such as vehicles, management structures, operating rules and regulations, as well as the social conventions which govern passengers' behaviour; and, thirdly, the mobility 'scapes', or the ways in which space and time were created, perceived and represented within a transport system. ${ }^{46}$ Trains and ships were technologies of mass or collective transportation, a means of getting from A to B. But they were also technologies that located people in relationship to each other in historically meaningful ways. On this basis, transport is increasingly approached as more than an institutional or functional context of everyday life, but as 'central to the production of society, establishing and reinforcing differences and inequalities between societies, groups and individuals' ${ }^{47}$

Shipping history has been under-represented in the debates that have animated transport historiography in recent years. The field has been more self-contained than the study of other transport modes, as Garth Wilson suggests, with its own publishing outlets, including the International Journal of Maritime History and the Northern Mariner. ${ }^{48}$ The newer approaches to maritime history, described earlier in this article, typically take their inspiration from fields other than the cultural turn in transport and mobility history. They are also weighted towards the age of sail and the 'many middle 
passages' of slaves, convicts and indentured labourers. ${ }^{49}$ There are fewer studies of the comparatively voluntary and routine journeys of the steam age, when more people were on the move than ever before. Passengers, in particular, have received very little attention from maritime historians.

As a necessary counterpoint to 'stability and fixity' in our conceptualization of community formations in nineteenth-century New Zealand, Ballantyne has pointed to the 'constant swirl of people and things' in and across colonial space. He conceives of specific sites, such as Gore, as dynamic 'knot-like conjunctures', produced out of linkages or networks that were variously small-scale and more wide-ranging. ${ }^{50}$ What I want to emphasize here, though, is the value of analyzing mobility in process and in practice, and concurrently expanding our definition of 'the local' to include vehicles on the move. What was the historical significance of the ship in making society mobile? This conceptual step can help to develop a more mobile approach to the colonial past and a more nuanced understanding of the ways in which moving from one comparatively stable site to another was 'imbued with socially-inscribed meanings'. ${ }^{51}$

In her work on the history of travel writing about New Zealand, Lydia Wevers has demonstrated the extent to which passengers were naturally preoccupied with the materiality of the shipboard experience and the 'conditions of travelling'. They were intent on communicating 'the action they are engaged on', and complaints about New Zealand's transport infrastructure were commonplace.$^{52}$ Harding, for one, was especially dismissive of a number of the Union Steam Ship Company's ships. Crossing between Hobart and Bluff, his travelling party amused itself through 'the interchange of as cutting remarks as we can think of on the deficiencies of the Warrimoo, and a little bridge in the evening. ${ }^{53}$ The company steamship Rotomahana (the 'Rotten Banana'), which later ferried the commissioners from Melbourne to Launceston, was renowned as the first screw steel ship south of the line. From Harding's perspective, the ship 'has at least a smell for each year of her age, and an indescribable stuffiness' ${ }^{54}$ On the basis of the company's monopoly over external shipping, he quipped, 'I can only regard the zest [for travel] as misplaced!' 55

Complaints about transport infrastructure and details of the shipboard experience could be dismissed as trivial and crude, the defining mark of an unsophisticated 'new chum', as Edward Wakefield's review of James Anthony Froude's Oceana, or England and her Colonies (1886) attests. ${ }^{56}$ From a transport history perspective, however, such details illustrate that transit time was not 'dead' time and that journeys had a social life. Remarks about awful smells and stuffy cabins point to shifting expectations about the culture of service at sea. As oceanic travel increasingly became an object of everyday consumption, this fostered new images of and attitudes towards 
sea transport. Shipping companies adopted new marketing techniques, such as guidebooks, to attract more passengers, but they also had to adapt to an increasingly cosmopolitan travelling public. Whereas transport history has traditionally neglected passengers, work on travel writing tends to privilege passengers' impressions and experiences over the material structures 'behind the scenes' that shaped mobility experiences. The challenge is to examine together the cultures of suppliers and users, to understand their reciprocal influence. When the Union Steam Ship Company's agent came down to Hobart wharf to see off the Warrimoo, 'obviously to receive compliments', after meeting with Harding and his companions 'he went away depressed, and, I hope, wiser'. ${ }^{57}$ To what extent were users able to influence business practice and the material culture of the 'trip'?

An amorphous social grouping like 'the travelling public' tells us little about the ways in which markers of social difference shaped or were constituted through consumption patterns. We probably have a better sense of the colonial mobilities deemed transgressive or threatening rather than commonplace and routine, and the introduction of measures to channel and contain steam-driven networks, particularly in the context of antiChinese agitation and the 'anxious politics' of the late nineteenth century. ${ }^{58}$ Heightened mobility was bound up with ideas of progress, modernity and civilization, yet these investments were, as Nan Seuffert highlights, 'co-constitutive with regulating groups of mobile people, or people characterized as mobile'. ${ }^{59}$ There is a danger, which scholars of the Indian Ocean point to, of taking mobility restrictions as clear evidence of their efficacy. They were often 'archives of mechanisms for control rather than proof that the controls worked'. ${ }^{60}$ Yoking 'race' too tightly to 'subversion' also risks sweeping over the ways in which the mobilities of 'minorities' could also be unremarkable, mundane or mainstream. Accessing histories of the routine is a more challenging endeavour. Everyday 'trips' across familiar waters did not generate an archive as rich as the travel narratives of tourists and empire travellers to New Zealand, or the debates surrounding legislative measures to restrict immigration on the grounds of race. But, again, this is where business archives, produced by the people who were invested in maintaining and developing transport technologies and systems, can offer new insights if revisited with questions of mobility cultures in mind.

Paying closer attention to the geographical spread of mobility networks might also illuminate the extent to which the enthusiasm for the trip routinely encompassed places beyond New Zealand's coastline. Calls to rethink the nation state as the primary spatial framework of historical analysis have increased in recent years. Transnational histories, as Giselle Byrnes emphasizes, can illuminate the extent to which New Zealand's cultural, political, economic and social trends have been 'part of a much larger 
canvas', while Ballantyne highlights the importance of looking 'under and beyond as well as across the nation' to stay faithful to 'the specific places' and 'particular locations' where people actually lived and built communities. ${ }^{61}$ Maritime history is ideally suited to the project of denaturalizing the nation and reframing New Zealand history through the translocal, transcolonial and transnational. It is also time to add the transoceanic to our approach. Shipping poses questions about what constitutes national space, for routes were not contained by the land-based infrastructure of a fixed track network. 'Satisfactory explanations and assessments' in maritime history, as Broeze remarks, 'can hardly be made without crossing borders and seas'. ${ }^{62}$

In this respect, Gordon Winder's argument that shedding a 'landlubber's gaze' for a 'seafarer's gaze' might 'lend a viewpoint, scale and character to the New Zealand imaginary that has been missing' is of particular importance. ${ }^{63}$ Winder offers a spatial analysis of Auckland's Queen Street as an extension of the wharf. Tracing the maritime networks which underpinned the economic life of the city in the early twentieth century, Winder argues that the city's history needs to be conceptualized in 'archipelago and network terms, as well as town-county-bush'. ${ }^{64} \mathrm{He}$ rightly concludes that 'historical geographies of New Zealand's maritime interconnectedness remain underdeveloped', yet what if we shifted perspective somewhat and followed ships on their itineraries away from, rather than towards, New Zealand? ${ }^{65}$

The Union Steam Ship Company's growth bolstered narratives of colonial progress and prosperity, and early company histories were nationally-focused, yet its operations were more wide-ranging, as Harding's experiences on both sides of the Tasman attest. In my own work I have explored the Union company's island trades, drawing on shipboard and port-town working cultures to locate New Zealand's colonial history in the maritime history of the Pacific world. ${ }^{66}$ More could be made of passengers' experiences along these transcolonial and inter-island trade routes, particularly as travel from New Zealand ports into the Pacific was fostered on a new scale from the late nineteenth century. People boarded Union Steam Ship Company steamers for a range of reasons, given the uneven but extensive pattern of commercial, political, religious and familial investment which stitched together New Zealand's Pacific empire. ${ }^{67}$ Increasingly, New Zealand-based colonists embarked for leisure, encouraged by the convenience of the company's monthly services and attracted by advertisements for "winter tours to the tropics'. On such tours, more time was usually spent on board ship than in island ports. To recover the social life of these sea journeys, mobility history can be brought into closer dialogue with recent work in imperial and global history which attends to the maritime setting. There is a broad consensus that 'new spatialities' emerged from the late nineteenth century, especially as steam displaced sail, yet there is less in-depth analysis of the 
ways in which individuals actually navigated these globalizing processes, as Tamson Pietsch remarks. Historians of empire have tended to focus on the land-based sites 'constructed by the trajectories of people, products and ideas', while overlooking or downplaying 'the process of travel and the progressive way in which individuals consciously sought to order the world around them'. ${ }^{68}$ For all the talk of time and space 'shrinking' under steam, transoceanic travel was still a major undertaking, where passengers encountered 'new social relationships, new climates, foreign peoples, difficult ideas'. Sea journeys were 'shifting spaces' in which diverse people developed ideas about a rapidly changing world. ${ }^{69}$

One example of regional mobility might suffice at this point. In 1908 John Bell Thomson, superintendent of Arrowtown's Lake County Hospital, embarked on a round-trip steamship tour of Tonga, Samoa and Fiji. After attending a wedding at Nuku'alofa, over 200 Islanders joined the ship to return to their homes in northern Tonga. Bell Thomson delighted in the 'favourable opportunity to study the natives'. They set about making themselves comfortable on deck 'as if no staring passenger existed', but soon invited him to partake of a meal of baked yam, followed by kava, singing and dancing. ${ }^{70}$ Bell Thomson probably went further than most European passengers, for other accounts of steamer travel in this period more often depicted indigenous deck passengers from a distance. ${ }^{71}$ The steamer was not only a space for encounters with 'travel happy' Islanders who made use of the Union Steam Ship Company's services to maintain older exchange networks; it was also a space where colonists encountered each other. ${ }^{72}$ When a number of Irish plantation overseers joined the ship at Fiji en route to Sydney, political discussions between men in the smoking room about 'wool and butter gave way to copra and sugar cane'. This provoked a heated argument about the treatment of Indian labourers. Bell Thomson observed that as one man had a facial scar, 'the result of a slash from a coolie's cane-knife, we outsiders said nothing, but thought a lot'. ${ }^{73}$ This was his 'difficult idea', for the steamship functioned as a space where New Zealanders 'encountered new worlds and new ways of being in the world' that 'rubbed up against' more familiar ideas. ${ }^{74}$

Steamships opened up more wide-ranging connections between New Zealand and the world. By the turn of the twentieth century, the Union Steam Ship Company had a stake in the operation of both trans-Pacific mail routes between Australia, New Zealand and North America, yet we still know comparatively little about the extent to which New Zealanders (Pocock's 'godwits', perhaps) traversed these routes, or the projects and ambitions which motivated their mobilities. ${ }^{75}$ Writing from Parnell to an American friend in 1897, Georgiana McConnell remarked that 'the new boats expect to do the distance between San Francisco and Auckland in 
seventeen days - as [Robert Louis] Stevenson described the route from New York to Samoa "Cross the Continent to San Francisco, and take the second turning to the left", Auckland please is the third' ${ }^{76}$ Her conceptual mapping of New Zealand's location in a regional transport 'scape' worked to contain the vastness of oceanic space. The enormity of the trans-Pacific distance from 'coast to coast' was also contained and humanized by the shipboard experience. Crossing between Auckland and San Francisco in 1886, the Irish playwright Dion Boucicault asserted that closer integration of the places connected by the Union company's routes rested not on official red tape, but on 'personal passenger intermixture': 'these are ties that people make and they are treaties that are not broken'. ${ }^{77}$ An advertisement for one trans-Pacific route echoed these sentiments. A 'peculiar social spirit, seldom found on the Atlantic liners exists here'. In the Atlantic trades larger passenger lists and shorter transit times meant only a 'form of acquaintance' with a select few could develop. On the trans-Pacific passage, by contrast, one more typically mixed 'with the whole of the company' ${ }^{78}$

Miles Fairburn has suggested that New Zealand was more quickly and intensively 'globalized' than most other societies because European colonization coincided with the revolution in transport and communications from the mid-nineteenth century. His vantage point is New Zealand 'anchored' as a point of convergence for a range of practices and ideas that flowed to us from over the seas. ${ }^{79}$ Yet again, however, I would suggest that histories of the routine passages from New Zealand ports into and across the Pacific (and beyond), and the nature of shipboard sociability along these routes (however short-lived), need to be written back into our histories of colonial modernity, to embrace more fully the processes which globalized New Zealand history. It is timely to revisit histories of business enterprises like the Union Steam Ship Company, to see better how they put us in the world.

This article, then, is meant to begin the work of opening up our thinking about the place of the sea in colonial culture and to contribute to the work already being done to incorporate transnational and international perspectives into New Zealand history. I have suggested some ways in which a new maritime approach might develop, drawing in particular on the perspectives that have recently enlivened histories of transport technologies in other global settings. To open up shipping history, traditionally bound by narrower economic and technical analyses, to the dynamic interplay between mobility subjects, objects and scapes, promises a fuller, more 'human' history of the use of the sea as a transport space. In turn, more metaphorical or symbolic references to oceanic voyaging and the colonial condition might be developed with specific reference to the interlinked cultures of transport production and use. And it is by following ships as they leave port, tracking their 


\section{Journal of New Zealand Studies}

operations across a wider oceanic canvas, that we can advance the project of denaturalizing the intellectual and physical borders of the nation state and, equally importantly, the divisions between land and sea.

1 Charles Lucas, Note on a Visit to Australia, New Zealand, and Fiji, in 1909, London, 1910, pp.6, 7.

2 The classic study is Russel Ward, The Australian Legend, Melbourne, 1966. For a reassessment see John Caroll, ed., Intruders in the Bush: The Australian Quest for Identity, 2nd edn, Melbourne, 1992.

3 J.G.A. Pocock, The Discovery of Islands: Essays in British History, Cambridge, 2005, especially ch.1. As one demonstration of the power of British maritime mythology in colonial New Zealand, Katie Pickles and Angela Wanhalla have shown how a shipwreck and rescue narrative in New Zealand colonial history was interpreted through imperial frames of reference: 'Embodying the Colonial Encounter: Explaining New Zealand's Grace Darling, Huria Matenga', Gender and History, 22, 2 (2010), pp.361-81.

4 Frank Broeze, 'Maritime History at the Crossroads: A Critical Review of Recent Historiography', in Broeze, ed., Research in Maritime History No. 9: Maritime History at the Crossroads: A Critical Review of Recent Historiography, St John's, Newfoundland, 1995, p.xiv; David M. Williams, 'The Progress of Maritime History, 1953-93', Journal of Transport History, 14, 2 (1993), pp.126-41.

5 Broeze, 'Maritime History at the Crossroads', p.xvii.

6 Ibid., p.xviii, n.21; Geoffrey W. Rice, ed., The Oxford History of New Zealand, 2nd edn, Auckland, 1992.

7 Broeze, 'Maritime History at the Crossroads', pp.xix-xxi.

8 Kären Wigen, 'Oceans of History', American Historical Review (AHR), 111, 3 (2006), p.717.

9 David Lambert, Luciana Martins and Miles Ogborn, 'Currents, Visions and Voyages: Historical Geographies of the Sea', Journal of Historical Geography, 32, 3 (2006), p.487.

10 Bernhard Klein and Gesa Mackenthun, eds, Sea Changes: Historicising the Ocean, New York and London, 2005; Trevor Bentley, Renate Bridenthal and Kären Wigen, eds, Seascapes: Maritime Histories, Littoral Cultures and Transoceanic Exchanges, Honolulu, 2007.

11 Glen O'Hara, “"The Sea is Swinging into View”: Modern British Maritime History in a Globalized World', English Historical Review, 124, 510 (2009), p.1130.

12 Marcus Rediker, 'Towards a People's History of the Sea', in David Killingray, Margarette Lincoln and Nigel Rigby, eds, Maritime Empires: British Imperial Maritime Trade in the Nineteenth Century, Suffolk, 2004, p.198.

13 Lewis R. Fisher, David J. Starkey and Malcolm Tull, 'Editors' Note', International Journal of Maritime History, 18, 2 (2006), pp.xiii-xiv. The contribution on the Pacific world was the least maritime in focus, with the ocean used for more metaphorical ends. Matt K. Matsuda, 'The Pacific', AHR, 111, 3 (2006), pp.758-80.

14 At the same time, maritime history is still peripheral in university research and teaching. This marginalization continues to provoke some introspection, with an acknowledgement that maritime historians need 'to be trained to ask broader, more comparative questions that address issues of interest to the wider historical profession'. Fischer, Starkey and 


\section{Sea Transport and Mobility in New Zealand Colonial History}

Tull, p.xiv. See also Lewis Johnman and Hugh Murphy, 'Maritime and Business History in Britain: Past, Present and Future?', International Journal of Maritime History, 19, 1 (2007), pp.265-70.

15 Giselle Byrnes, ed., The New Oxford History of New Zealand, Melbourne, 2009.

16 Erik Olssen, 'The Seamen's Union and Industrial Militancy, 1908-13', New Zealand Journal of History (NZJH), 19, 1 (1985), pp.14-37.

17 Some representative works include: Neill Atkinson, Crew Culture: New Zealand Seafarers Under Sail and Steam, Wellington, 2001; Helen Beaglehole, Always the Sound of the Sea: The Daily Lives of New Zealand's Lighthousekeepers, Nelson, 2009; Jack Churchouse, Glamour Ships of the Union Steam Ship Company of New Zealand, Ltd., Wellington, 1981; David Johnson, New Zealand's Maritime Heritage, Auckland, 1987; Gavin McLean, New Zealand Tragedies: Shipwrecks and Maritime Disasters, Wellington, 1991; Gavin McLean, Captain's Log: New Zealand's Maritime History, Auckland, 2001; Harry Morton, Whale's Wake, Dunedin, 1982. See also Marianne Kraack, 'Selective Bibliography of New Zealand's Maritime History', Master of Library and Information Studies, Victoria University of Wellington, 1996; New Zealand Maritime Index, http:// www.nzmaritimeindex.org.nz/izlistpubs.php?db=Y\&dm=\&ds, accessed 28 May 2011.

18 Frank Broeze, 'From the Periphery to the Mainstream: The Challenges of Australia's Maritime History', The Great Circle: Journal of the Australian Association for Maritime History, 11, 1 (1989), p.6.

19 Paul Star, 'Humans and the Environment in New Zealand, c.1800 to 2000', in Byrnes, ed., The New Oxford History of New Zealand, p.68.

20 David Hastings, Over the Mountains of the Sea: Life on the Migrant Ships, 1870-1885, Auckland, 2006; Megan Hastings, Over the Wide and Trackless Sea: The Pioneer Women and Girls of New Zealand, Auckland, 2008; Jenny Robin Jones, No Simple Passage: The Journey of the "London" to New Zealand, 1842: A Ship of Hope, Auckland, 2011.

21 Pocock, p.11. My suggestion that the ocean recedes is not meant to imply that migration histories are necessarily insular or 'nation bound'. Giselle Byrnes, 'Nation and Migration: Postcolonial Perspectives', NZJH, 43, 2 (2009), pp.123-32.

22 Chris Hilliard, 'Colonial Culture and the Province of Cultural History', NZJH, 36, 1 (2002), p.2. Māori migration narratives are relegated to mythology or 'pre-history'. For a critique and reassessment see Nepia Mahuika, 'Revitalizing Te Ika-a-Maui: Migration and the Nation', NZJH, 43, 2 (2009), pp.133-49. For a more wide-ranging discussion of the enduring tensions between imperial and indigenous maritime imaginaries see Elizabeth DeLoughrey, Routes and Roots: Navigating Carribean and Pacific Island Literatures, Honolulu, 2007.

23 Yet most waka traditions tend to underpin the expression of iwi identity and its relationship to land-based territory and mobility, rather than the original oceanic passage: Angela Wanhalla, 'Maori Women in Waka Traditions', in Lyndon Fraser and Katie Pickles, eds, Shifting Centres: Women and Migration in History, Dunedin, 2002, pp.25-26. Pocock makes a similar observation in The Discovery of Islands, p.5.

24 For some shipping statistics, see Muriel Lloyd Prichard, An Economic History of New Zealand to 1939, Auckland, 1970. It must be acknowledged, however, that a number of studies go beyond traditional economic history and the compilation of statistics. Studies include path-breaking work on Māori engagement with maritime industry in the colonial period, notably Hazel Petrie, Chiefs of Industry: Māori Tribal Enterprise in Early Colonial New Zealand, Auckland, 2006. For a more general discussion of maritime transport which goes beyond the migrant passage see James Watson, Links: A History of Transport and New Zealand Society, Wellington, 1996, especially chs 1-3. 


\section{Journal of New Zealand Studies}

25 Hilliard, p.8.

26 Ballantyne highlights the incongruity of the term 'settler' in 'On Place, Space and Mobility in Nineteenth Century New Zealand', NZJH, 45, 1 (2011), p.63. For an Australian perspective on the relationship between mobility and colonization see Georgine Clarsen, 'Mobility in Australia: Unsettling the Settled', in Gijs Mom, Gordon Pirie and Laurent Tissot, eds, Mobility in History: The State of the Art in the History of Transport, Traffic and Mobility, Neuchatel, 2009, pp.123-8.

27 Edward Harding, cit. Stephen Constantine, ed., Dominions Diary: The Letters of E.J. Harding, 1913-1916, Halifax, 1992, p.113; Pocock, p.6.

28 Harding, cit. Constantine, p.113.

29 For one discussion of the emergence of these values see Wolfgang Schivelbusch, The Railway Journey: The Industrialization of Time and Space in the 19th Century, Berkeley, 1986, pp.195-7. A brief account of changing historical senses of mobility can be found in Tim Cresswell, On the Move: Mobility in the Modern Western World, New York and London, 2006, pp.9-21.

30 Colin Divall, 'Mobilizing the History of Technology', Technology and Culture, 51, 4 (2010), p.945.

31 Otago Witness, 5 March 1853, p.4.

32 Sewell, cit. Watson, p.151.

33 Nelson Examiner (NE), 4 October 1851, p.126.

34 Ibid.

35 Ballantyne, 'On Space, Place and Mobility', pp.55-61. For a general history of the relationship between transport and national integration, see Watson, especially ch.3.

36 NE, 4 October 1851, p.126.

37 For a business history see Gavin McLean, The Southern Octopus: The Rise of a Shipping Empire, Wellington, 1990.

38 New Zealand Official Year Book, Wellington, 1893, p.332.

39 Evening Post, 22 November 1905, p.8.

40 James Smithies, 'The History of Technology and the History of New Zealand', Journal of New Zealand Studies (2006), pp.114, 116.

41 Divall, p.945.

42 This has been highlighted with respect to railroad history. Gijs Mom, Colin Divall and Peter Lyth, 'Towards a Paradigm Shift? A Decade of Transport and Mobility History', in Mom, Pirie and Tissot, p.28.

43 Broeze's work is central here. In two key articles he placed Australia and New Zealand in the same interpretative frame, for they formed one shipping market throughout the nineteenth and twentieth centuries. Broeze, 'Distance Tamed'; Broeze, 'Private Enterprise and Public Policy: Merchant Shipping in Australia and New Zealand, 1788-1992', Australian Economic History Review, 32, 2 (1992), pp.8-32.

44 Divall, p.942.

45 Mom, Divall and Lyth, p.19.

46 Ibid., p.30.

47 Colin Divall and George Revill, 'Cultures of Transport: Representation, Practice and Technology', Journal of Transport History, 26, 1 (2005), pp.104-5. See also Tim Cresswell, 'Towards a Politics of Mobility', Environment and Planning D: Society and Space, 28, 17 (2010), pp.17-31. 


\section{Sea Transport and Mobility in New Zealand Colonial History}

48 Garth Wilson, 'The Mobility Paradigm and Maritime History', in Gijs Mom, Peter Norton, Georgine Clarsen and Gordon Pirie, eds, Mobility in History: Themes in Transport, Neuchatel, 2010, pp.13-15.

49 Emma Christopher, Cassandra Pybus and Marcus Rediker, eds, Many Middle Passages: Forced Migration and the Making of the Modern World, Berkeley, 2007.

50 Ballantyne, 'On Place, Space and Mobility', pp.59-60, 61.

51 Divall, p.950.

52 Lydia Wevers, Country of Writing: Travel Writing and New Zealand, 1908-1900, Auckland, 2002, pp.163-6.

53 Harding, cit. Constantine, p.77.

54 Ibid., p.145.

55 Ibid., p.113.

56 Wevers, Country of Writing, pp.150, 166. See also Wevers, ed., Travelling to New Zealand: An Oxford Anthology, Auckland, 2000, p.3.

57 Harding, cit. Constantine, p.75.

58 Ballantyne, 'On Place, Space and Mobility', p.65.

59 Nan Seuffert, 'Civilisation, Settlers and Wanderers: Law, Politics and Mobility in Nineteenth Century New Zealand and Australia', paper presented at the Legal Intersections Research Centre seminar series, University of Wollongong, 17 May 2011.

60 Heather Goodall, Develeena Ghosh and Lindi R. Todd, 'Jumping Ship - Skirting Empire: Indians, Aborigines and Australians across the Indian Ocean', Transforming Cultures e-Journal, 3, 1 (2008), pp.47-48.

61 Giselle Byrnes, 'Introduction: Reframing New Zealand History', in Byrnes, ed., The New Oxford History of New Zealand, p.1; Ballantyne, 'On Place, Space and Mobility', pp.50, 58; Ballantyne, 'Thinking Local: Knowledge, Sociability and Community in Gore's Intellectual Life, 1875-1914', NZJH, 44, 2 (2010), pp.138-56.

62 Broeze, 'Maritime History at the Crossroads', p.x.

63 Gordon Winder, 'Seafarer's Gaze: Queen Street Business and Auckland's Archipelago, 1908', New Zealand Geographer, 62, 1 (2006), p.51.

64 Ibid., p.55

65 Ibid., p.62.

66 Frances Steel, Oceania Under Steam: Sea Transport and the Cultures of Colonialism, c.1870-1914, Manchester, 2011.

67 Damon Salesa, 'New Zealand's Pacific', in Byrnes, ed., The New Oxford History of New Zealand, pp.149-72.

68 Tamson Pietsch, 'A British Sea: Making Sense of Global Space in the Late Nineteenth Century', Journal of Global History, 5, 3 (2010), pp.424, 427.

69 Pietsch, p.446.

70 'Newspaper articles and notes relating to John Bell Thomson, Chisholm, Jocelyn Bell (1928-2010)', MS-Papers-10501, Alexander Turnbull Library (ATL), Wellington.

71 Steel, Oceania Under Steam, pp.194-7.

72 Damon Salesa, “"Travel Happy” Samoa: Colonialism, Samoan Migration and a "Brown Pacific"', NZJH, 37, 2 (2003), pp.171-88; Steel, Oceania Under Steam.

73 'Newspaper articles and notes relating to John Bell Thomson'. 


\section{Journal of New Zealand Studies}

74 Pietsch, p.445.

75 Frances Steel, 'Via New Zealand Around the World: The Union Steam Ship Company and the Trans-Pacific Mail Lines, 1880s-1910s', in Prue Ahrens and Chris Dixon, eds, Coast to Coast: Case Histories of Modern Pacific Crossings, Newcastle-upon-Tyne, 2010, pp.59-76; Pocock, p.14.

76 McConnell to Keely, 21 January 1897, Dr Leslie Keely correspondence with Mrs Georgiana McConnell, MS-Papers-1116, ATL.

77 Aroha and Ohinemuri News, 13 February 1886, p.5.

78 Trumbull White, Pacific Tours and Around the World, Chicago, 1900, pp.24, 154.

79 Miles Fairburn, 'Is There a Good Case for New Zealand Exceptionalism?', in Tony Ballantyne and Brian Moloughney, eds, Disputed Histories: Imagining New Zealand's Pasts, Dunedin, 2008, p.165. 